\title{
Corrosion-resistant lightweight metallic bipolar plates for PEM fuel cells
}

\author{
YUE HUNG $^{1}$, K. M. EL-KHATIB ${ }^{2 * *}$ and HAZEM TAWFIK ${ }^{1}$ \\ ${ }^{1}$ Institute for Research and Technology Transfer (IRTT), Farmingdale State University of New York, USA \\ ${ }^{2}$ Chemical Engineering and Pilot plant Department, National Research Center, Dokki, Giza, Egypt \\ (*author for correspondence, e-mail: kamelnrc@hotmail.com)
}

Received 20 July 2004; accepted in revised form 11 December 2004

Key words: Polymer Electrolyte Membrane (PEM), metallic bipolar plate, corrosion resistant

\begin{abstract}
Corrosion resistant treated metal bipolar plates with higher rigidity and electrical conductivity than graphite were developed and tested for PEM fuel cell applications. Six replicas of single cells were used three of which were made of graphite composites bipolar plates and the other three of the treated metallic plates. A Membrane Electrode Assembly (MEA) with $5.55 \mathrm{~cm}^{2}$ active electrode areas, $0.3 \mathrm{mg} \mathrm{cm}^{-2} \mathrm{Pt}$ loading and Nafion membrane 115 was fitted to each cell and operated under identical conditions. The experimental testing was conducted at room temperature $\left(20^{\circ} \mathrm{C}\right)$. The average value of the data obtained for the three graphite cells was plotted. Similarly, the average value of the data obtained for the three treated metal cells was plotted on the same graph for comparison. Generally, the treated metal bipolar plate provided at least $12 \%$ saving in hydrogen consumption in comparison to graphite. This is attributed to the lower bulk and surface contact resistance of the metal used in this study in relation to graphite. The results of lifetime testing, conducted at room temperature under variable loading showed no indication of power degradation due to metal corrosion for at least 1500 hours.
\end{abstract}

\section{Introduction}

The cost of fuel cell components and durability are important issues that need to be dealt with, especially when we compare the cost of electricity generated by PEM fuel cells with that generated by conventional power plants using fossil fuels. In addition, for PEM fuel cells to be able to compete with the currently available power systems fuel cell cost must be reduced, at least, five fold. On the other hand, the cost of hydrogen currently ranges between US $\$ 10$ and $20 \mathrm{G} \mathrm{J}^{-1}$ [1], which is not as competitive as fossil fuel in the energy market. However, the cost of hydrogen is expected to decrease in the near future as research and development focus on the production, storage and transportation more economically. Meanwhile, the cost of conventional fossil fuel is expected to increase due to future anticipated scarcity and additional environmental taxes imposed. Taking these expectations into account, the costs of both hydrogen and fossil fuel are predicted to merge by the year 2030 at a rate of US\$6.2 $\mathrm{G} \mathrm{J}^{-1}$. Then, these costs are expected to diverge with a further decrease in the hydrogen cost and a further increase in the fossil fuel cost [2].

A literature review on fuel cell efficiency indicates that most studies have dealt with energy analysis of PEM fuel cell systems with varying degrees of co-generation [3-6]. Some articles have focused on the economic aspects of the fuel cell used in various applications [7-10]. Barbir and Gomez [11] described the interrelation of fuel cell economics with operating efficiency. They analyzed the efficiency and economics of a $10 \mathrm{~kW}$ DC power PEM fuel cell with an active area of $780 \mathrm{~cm}^{2}$ developed by Energy Partners Inc. in terms of various load profiles and cost scenarios [12]. However, they found it is extremely important to determine an operating efficiency range where the fuel cell is economically and technically usable. In other words, there is a fuel cell efficiency range where the annual fuel cost and the electricity cost will not be significantly affected by any major variations in the fuel cell efficiency. Therefore, the current study focused on a comparison between the effects of treated metal and graphite bipolar plates on hydrogen consumption, fuel cell efficiency and durability.

\section{Experimental}

The experimental set-up consisted of six fuel cells encompassed in a negative pressure test station and connected to data acquisition system (DASYLab 5.6 software). The operating parameters like current, voltage and power as well as temperature and gas volume flow rate of the reactants of all the fuel cells were recorded with the data acquisition system. The test 
station provided the reactants (Hydrogen and air) and controlled the electric load while the data acquisition system measured and recorded the information. Both air and hydrogen were regulated by mass flow meters (Type FMA-A2300, Omega). The fuel cells were connected to a programmable electronic load (MCL488 DYNALoad) that was used in increments of constant current mode.

Membrane Electrode Assemblies, with $5.55 \mathrm{~cm}^{2}$ active electrode area were loaded into six replicas of single cells. Three of these were made of graphite composites and the other three were made of treated metal "patent pending".

All cells were operated under identical conditions at a room temperature at $20^{\circ} \mathrm{C}$, air flow rate of $1350 \mathrm{~cm}^{3} \mathrm{~min}^{-1}$, and hydrogen pressure $20 \mathrm{psig}$. The hydrogen was dead-ended at the exhaust manifold for all cells. The data from the three graphite cells were averaged and plotted and other metal cell data were similarly treated and plotted on the same graph for comparison. Each single cell test fixture consisted of two bipolar plates that contained a serpentine of rib channel patterns to allow the passage of hydrogen and air to the anode and cathode, respectively. The Membrane Electrode Assemblies (MEAs) were acquired from Ion Power Inc., with double-sided Electrodes and $0.3 \mathrm{mg} \mathrm{cm}^{-2} \mathrm{Pt}$ loading and Nafion membrane 115 (DuPont) was used. The fuel cell operated with ambient air obtained from an industrial compressor and dry industrial grade hydrogen supplied by a metal hydride storage tank.

\section{Results and discussion}

Figure 1 shows the polarization curves for both treated metal bipolar plate and composite graphite. The results indicate better performance for the treated metal bipolar plate in comparison with graphite. For example, at a $200 \mathrm{~mA} \mathrm{~cm}{ }^{-2}$ current density the cell voltage outputs were 0.48 and $0.41 \mathrm{~V}$ for treated metal and composite graphite bipolar plate, respectively. Also, Figure 2 depicts that the maximum output power density was 0.1 and $0.08 \mathrm{~W} \mathrm{~cm}^{-2}$ for treated metal and composite graphite, respectively. This is attributed to the lower

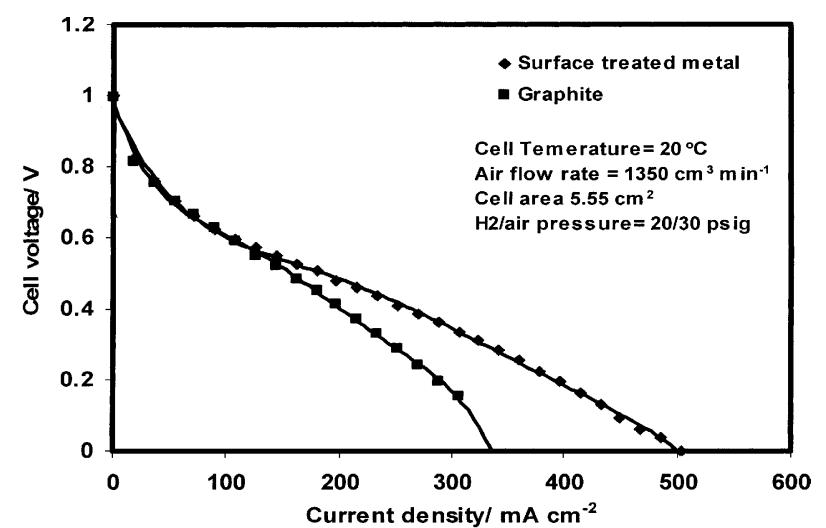

Fig. 1. Polarization curves for treated metal and graphite.

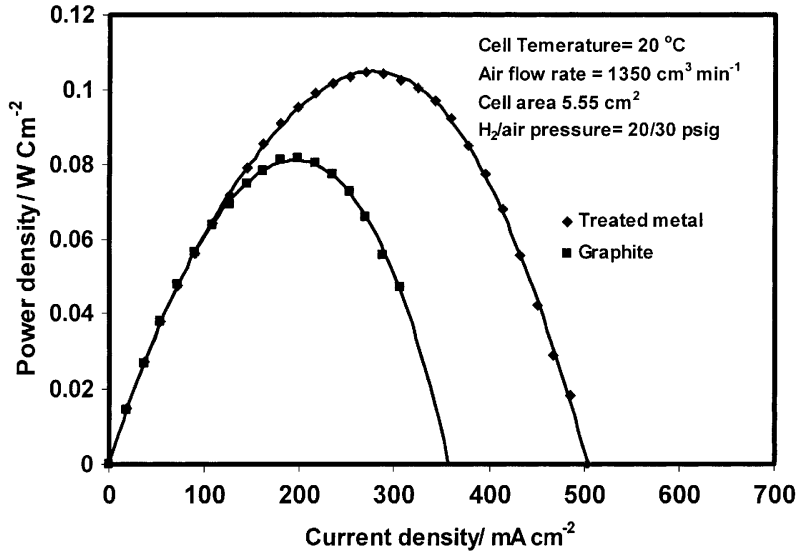

Fig. 2. Power curves for treated metal and graphite.

bulk and contact resistances of metal bipolar plate compared to graphite.

Figure 3 shows the distribution of power density and hydrogen consumption per watt vs. current density for both treated metal and composite graphite bipolar plates. The results showed that the hydrogen consumption per watt using metal bipolar plate is lower than that for graphite. For example, the hydrogen consumption per watt at current density $200 \mathrm{~mA} \mathrm{~cm}{ }^{-2}$ was 12.82 and $15.86 \mathrm{~cm}^{3} \mathrm{~W}^{-1}$ when using treated metal and composite graphite as bipolar plates, respectively.

Preliminary experimental results showed at least $12 \%$ savings in hydrogen consumption because of the lower bulk and contact resistance of metal compared to graphite. A simple cost analysis of electric energy losses as heat due to the bulk resistance of aluminum and graphite showed that aluminum bipolar plates save electrical energy from converting to heat in the amount of $\$ 1060$ per year for a $500 \mathrm{~kW}$ unit.

The power density and fuel cell efficiency distributions for treated metal and graphite bipolar plate performance at different current density are depicted in Figure 4. The efficiency using treated metal is higher than for graphite. For example, the efficiency at $200 \mathrm{~mA} \mathrm{~cm}{ }^{-2}$ was $46.77 \%$ compared with $37.79 \%$ when using metal and composite graphite as bipolar plate.

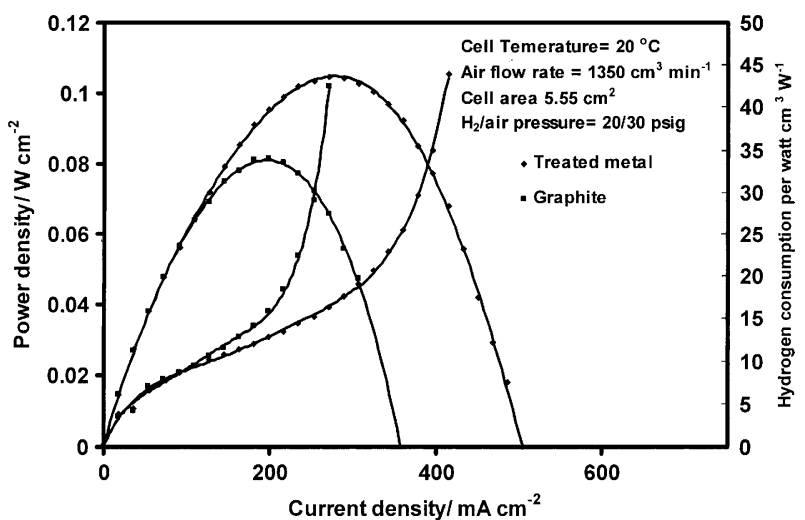

Fig. 3. Power density and hydrogen consumption vs. current density. 


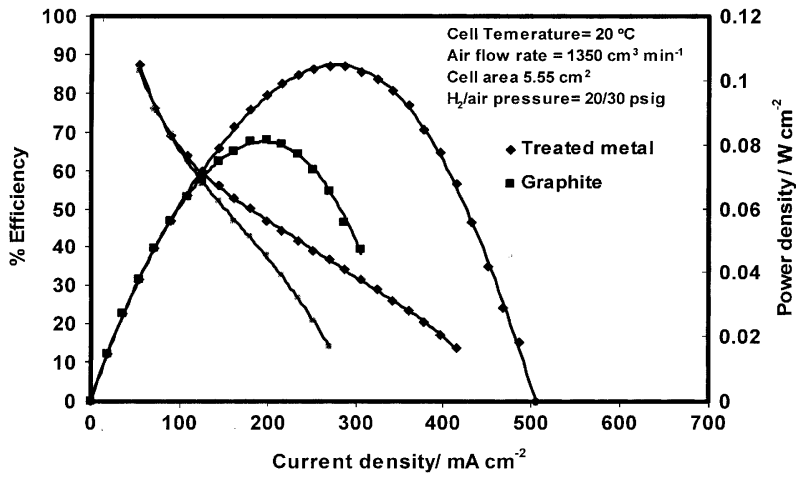

Fig. 4. Power density and efficiency vs. current density.

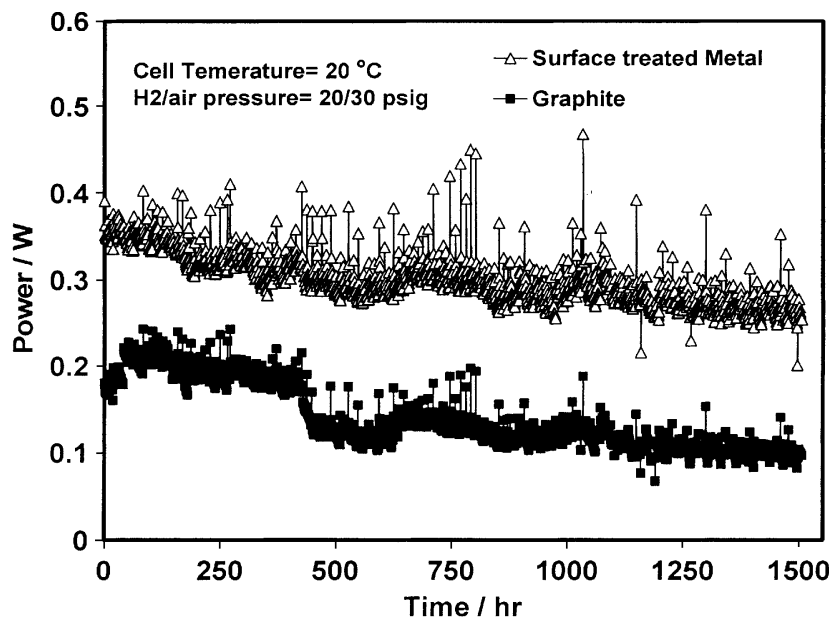

Fig. 5. Power output vs. time (life time test) under cyclic loading.

The six fuel cells were tested under the same operating conditions and each cell powered the exact variable loading. The treated metal bipolar plates performed for $1500 \mathrm{~h}$ with no sign of power degradation due to corrosion. The output power of the three aluminum fuel cells were averaged and plotted in Figure 5. Similarly, the data obtained for the other three graphite fuel cells were statistically treated and plotted on the same graph for comparison.

The parallel and very similar performance trends of graphite and treated metal provide clear proof that no power degradation was caused by metal corrosion. Graphite is known to be non-corrosive and therefore it can be used as a reference of comparison. In this study, industrial hydrogen and air were used. Air was provided by industrial compressors. Oil, particles and impurities were not effectively filtered from the industrial compressors and hydrogen tanks before feeding the fuel cells. This explains the slight reduction in power observed in Figure 5.

\section{Conclusions}

The results shown above indicate that treated metal bipolar plates can be used in PEM fuel cells because they have a higher performance than graphite. Metal bipolar plates showed a $12 \%$ saving in hydrogen consumption and higher efficiency in relation to graphite. The metallic bipolar plates performed for $1500 \mathrm{~h}$ with no sign of power degradation due to corrosion.

\section{References}

1. Kazim Ayoub, Renewable Energy 26 (2002) 4798.

2. M. Abdallah, S.S. Asfour and T.N. Veziroglu, Int. J. Hydrogen Energy 24(6) (1999) 505.

3. M.A. Rosen and D.S. Scott, Int. J. Hydrogen Energy 12 (1987) 837.

4. J.H. Morehouse, J. Solar Energy Eng. (1988) 110.

5. P.F. Oosterkamp, A.A. Goorse and L.J. Blomen, J. Power Sources 41 (1993) 239.

6. F. Barbir, Proceedings of 11th World Hydrogen Energy Conference, Stuttgart, Germany, (1996) $1695 .$.

7. N. Ibl and P.M. Robertson, Electrochim Acta 18 (1973) 897.

8. J. Newman, Electrochim Acta 24 (1979) 223.

9. T.N. Veziroglu, 'Hydrogen energy system: application and economics', Report from Clean Energy Research Institute, University of Miami, Coral Gables, FL, (1990).

10. W.P. Teagan, J. Bentley and B. Barnett, J Power Sources 71 (1998) 80.

11. F. Barbir and T. Gomez, Int. J Hydrogen Energy 21 (1996) 891.

12. F. Barbir, Progress in PEM fuel cell system development. In: Yurum Y. (Ed), 'Hydrogen Energy System', (NATO ASI Ser. E. vol. 295, 1995) 203. 